Original article

\title{
LIGHTS ON SABAZIUS CULT IN EGYPT "THROUGH AN UNPUBLISHED RARE HAIRPIN"
}

\author{
Masoud, A. \\ Archaeology dept., Faculty of Arts, Ain Shams University, Cairo, Egypt \\ E-mail:abdoumasoud@yahoo.com
}

\begin{abstract}
This article deals with a hairpin carved out of Ivory which has been discovered by an Egyptian archaeological mission during excavation works in $1982^{(a)}$ at the site of the ancient city Sais ${ }^{(b)}$, and was kept in Tanta museum ${ }^{(c)}$. Researches about such Greco-Roman Egyptian artifacts are very rare and that is what led me to study the case of Sais hairpin. Within the framework, I provide a detailed description of the hairpin, an interpretation of the form, examples of Sabazius hands, cult of Sabazius within the Roman Empire, Sabazius in Egypt and in the end, the significance of the hairpin with a conclusion.
\end{abstract}

Keywords: Hairpin, Jupiter Dolichenus, Sabazius, Serapis, benedictio latina.

\section{Introduction}

The total length of the hairpin is $14.2 \mathrm{~cm}$, fig. (1-a, b, c). The head of the pin was carved in the shape of an open right human hand in non-naturalistic proport-ions, with palm turned outwards with long fingers; two of them are folded into the palm, namely the little and ring fingers, the other three; the thumb, the index, and the middle are extended outspread. The fingers are long and slender with little incised markings of the phalanges. The hand with the wrist leaning on a long staff is pointed at the other end. The hand has no ornaments except for a small globular or semi-round object between the extended three fingers. The staff itself is plain only the wrist is encircled with a stylized bracelet in the form of a snake with two coils.

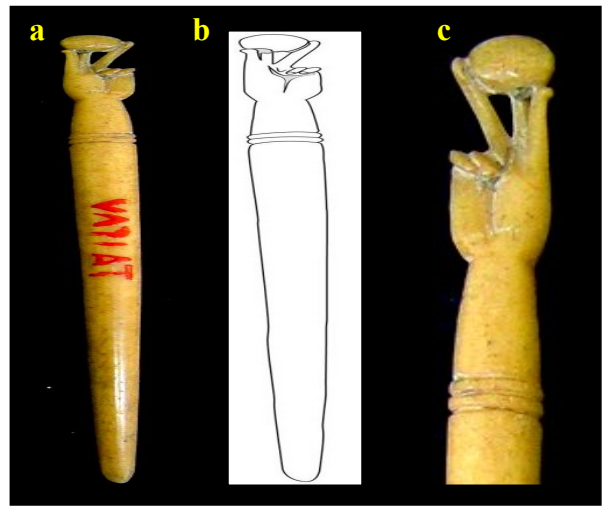

Figure (1-a, b, c) An ivory hairpin, Tanta museum, Egypt. (Inv. TA. 1287). 


\subsection{Hands of Jupiter Dolichenus}

Hairpins representing human hands are widespread. They can be found in the whole Roman Empire and are one of the most common groups of Roman hairpins with figural decoration. Our pin agrees with type 3, B, D, F for David Bartus classification and more precisely type 3, B, fig. (2-a) [1]. The hairpins of this category are generally made of bone, and their postures resemble the so-called benedictio Latina [2]; we find three fingers - thumb, index and middle - are holding a globular object, while the ring and the little fingers are bent to the palm [1]. The wrist is decorated with a pattern which can be interpreted as a stylized bracelet consists of one or more incised lines. Human hand motif was generally widely used in Greco-Roman artifacts, and the most notable one is the popular hand which is to be ascribed to Jupiter Dolichenus cult, fig. $(2-b)^{(d)}$, but we find it as an empty votive hand with all five fingers outstretched, which is a simple posture. But here, our hairpin has a characteristic feature which must be treated independently; the posture of the hand as well as the shape of the object that is held by the three fingers and the decoration of the wrist. If we take a closer look at the previous description, we can find that our hand has specific features, including the action of fingers gives the Latin benediction (benedictio Latina); where three fingers are extended, whereas the little and the ring fingers are bent. In addition, most of these hands usually come as the right one, so the hand presumably evokes another god; and clearly, one can identify this hand totally as a symbol hand, such as the hand associated with the originally Phrygian god Sabazius [1, 3]. The common form of representation of Sabazius is as a divinity of a Phrygian origin with complete Phrygian clothes, and his hand, usually the right one, is raised in the so-called benedictio latina gesture. The features of his cult are as statuettes and reliefs show us Sabazius cladding in Phrygian costume, fig. (2-c) with both hands upraised in Latin benediction ${ }^{(\mathrm{e})}$. His feet are placed on a ram's head, and on top of his head there is a crescent moon with knobs at each end [3,4].
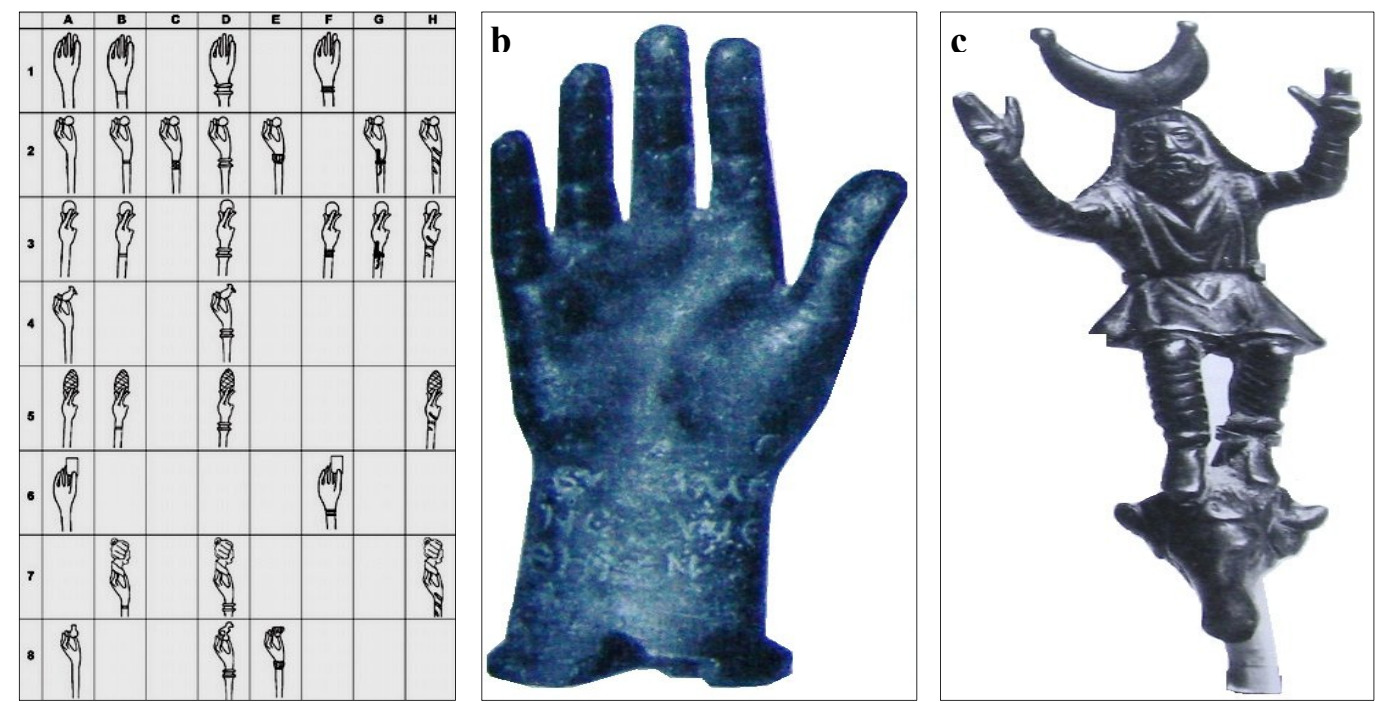

Figure (2) ‥ Classification of David Bartus. (Bartus, D., 2012) ‥ a hand of Jupiter Dolichenus. (Wirth, H., 2010) ‥ a statuette of Sabazius. (Johnson, S., 1984). 1598.

\subsection{Hands of Sabazius.}

Through the iconographical evidences, we find a series of votive bronze hands that come to characterize the cult of Sabazius. These hands are the most striking feature and datable Sabaziusmonuments with the same Latin 
benediction gesture and the snake on the wrist. For example, a bronze right hand found in Pompeii, fig. (3-a), $1^{\text {st }}$ century A.D. ${ }^{(f)}$ [5], shows the thumb, the index, and the middle fingers extended whereas the little and the ring fingers folded into the palm. There is also a similar bronze right hand ( $3^{\text {rd }}$ century A.D.) of which three fingers are extended, the little and ring fingers are folded into the palm, fig. (3-b) ${ }^{\text {(g) }}$ [5]. Some of these hands are relatively simple hands with few symbolic items especially the pine-cone of Dionysos and the snake, but others are supplied with several symbols, where Sabazius is associated with divinities that played an important role in his religion and iconography. The relation between Sabazius and the pine-cone is attested through many iconographical evidences, where the pine-cone beside the snake present the most important symbols of Sabazius. A bronze right hand dated from $1^{\text {st }}$ to $2^{\text {nd }}$ century A.D. ${ }^{\text {(h) }}$, shows the gesture of Sabazius[5]; the thumb, the index, and the middle are upraised, the little and the ring fingers are bent into the palm, the extended fingers holding a pine-cone, fig. (3-c), a snake coils around the wrist; the snake's head is visible at the beginning of the thumb. Another bronze right hand rests on a long wrist with a hollow in the beginning, fig. (3-d) [5]. A pine-cone is between the thumb, the index, and the middle, that are extended and the little and the ring fingers are bent (i). Beside the pine-cone and the snake, the iconography of Sabazius' hands are supported in art by rich series of various major and secondary attributes and symbols in reliefs -about thirty in all [3]as a figure of bearded Sabazios with a moustache sitting in the palm of the hand, wearing a Phrygian cap, a short tunic with long sleeves, his hands are upraised in the same characteristic gesture of benediction as usual and his feet often rest on a ram's head; he is sometimes thought to have been originally a ramgod [3]; as well as other numerous symbols like scales, whip, palm branch, a flaming altar, a sacrificial table [6] or a tray with offerings [7], Amphora or krater, sacrificial knife and a phallus $[5,8]$, and a loaf of bread, sometimes divided into four parts [5]. Sabazius is often pictured with animal and bird figures as a turtle, a frog, a bee, a lizard, an owl and elsewhere on the hand are shown as a scarab. We also find the eagle of Zeus, which frequently surmounts Sabazius' extended index and middle fingers perching on a thunderbolt on the bronze hands [9], which shows Sabazius associated with Zeus. A series of musical instruments like the sistrum of Isis, a cymbal or two cymbals, a double flute (Phrygian pipes) and the lyre of Apollo are found on some examples $[8,10]$. Few hands have on the wrist a Semi-circular cave (caverna) enclosing the figure of a reclining mother nursing her child. Sabazius is associated with Mercury; not less than twelve of the known hands are decorated with busts or heads of this god wearing a winged petasus [5], in addition to his winged staff of caduceus which shows Sabazius as a god of afterlife [9]. Different museums acquire several examples of hands that are mostly decorated with these different symbols and items and highly valued by collectors. Two very similar votive bronze right hands were found inside a shrine in a house (II, I, 12) at Pompeii in 1954. One of them shows several symbols like a seated figure of Sabazius in the palm against the index and middle. His arms are raised up, the right hand is in benediction gesture, fig. $(3-\mathrm{e})^{(\mathrm{j})}[7,11$, 12]. His head carries the Phrygian cap with flaps falling down the shoulders, surmounted by a crescent moon, and the god is dressed in a short tunic bound at the waist with high shoes. His feet are resting on the head of a ram. On the tip of the thumb, turned slightly outward, there is a pine-cone. We find on the wrist a well-defined figure of a reclining woman nursing a baby in a sort of cave. Above the cave, there is a tray with offerings. A long bearded serpent which stretches out along the ring finger is depicted on the back sucking liquid from a vase. There is 
also a branch with a serpent wrapped around, a winged caduceus, a knife, a Phiale, a pair of cymbals, a scale, an amphora, frogs or toads, and also a pinecone. There is another bronze votive hand of Sabazius ( $1^{\text {st. }}$ century A.D.), fig. (3f) ${ }^{(\mathrm{k})}[5,10,13,14]$; its thumb, index and middle are extended, the little and ring fingers are folded into the palm. A figure of bearded Sabazius with a moustache is sitting in the palm of the hand against the index and middle fingers. The god is wearing a Phrygian cap, a short tunic with long sleeves, his hands upraised in the same characteristic gesture of benediction as usual and his feet rest on a ram's head. A semi-circular cave is enclosing the figure of a reclining mother nursing her child on the wrist. The pinecone of Dionysos is on the tip of the thumb. There is also a pair of scales, four insects, a snake whose head is missing, a winged caduceus, a tree, a lizard, a toad, two flutes, and a whip, a pair of cymbals, a scarab, a loaf of bread and a sistrum. The most problematic item or symbol with our pin is the globular or semi-round object between the extended three fingers that is not a pine- cone, which is often stylized in natural proportions with Sabazius hands, figs. (3-c, d, e) [5]. The explanation of the item of our hairpin is not possibly easy (figs. 1a-b) because of its absence among the decorations that cover Sabazius hands. Some scholars presented few interpretations for the identification of this globular object. Some supposed that a globular item represents an apple, a pomegranate or an egg [1]. It is depicted here, as the Ex-voto hands of Sabazius show us, in order to be a food for the snake that is coiling upwards on the wrist and moving its head towards the object between the fingers to eat it $[1,5,15]$,or perhaps the globular item here is a bead and has no symbolic function, it is used just as a decorative element of the hairpin. But it may be a globular symbol because Sabazius is identified with so many principal gods as Zeus, Serapis and Dionysos.

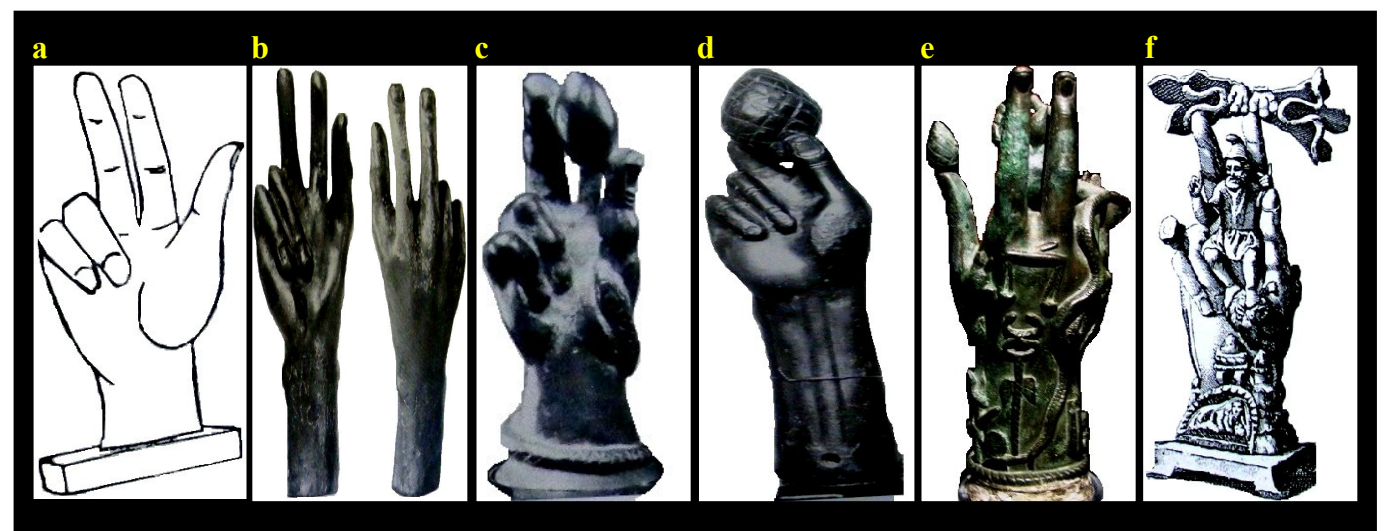

Figure (3) ‥ A hand of Sabazius (Vermaseren, M.1983), ㅁ. a bronze right hand of Sabazius (Vermaseren, M.1983), c. a hand is holding the pine-cone (Vermaseren, M.1983), d. a hand rests on a wrist (Vermaseren, M.1983), e. a votive bronze right hand of Sabazius shows several symbols (Conticello, B. \& al., 1990), f. a bronze hand of Sabazios found at Herculaneum. (Turcan, R., 1993)

\section{Cult of Sabazius}

\subsection{Cult of Sabazius in the Greco-Roman world}

The most common form of the divinity name is $\Sigma \alpha \beta \alpha \dot{\zeta} \zeta$ lo in Greek and Sabazius in Latin. This is usual in literary sources and occurs in inscriptions found in different places of the Roman
Empire $^{(1)}$ [9]. The earliest evidence of Sabazius cult is known in Greece as early as the $5^{\text {th }}$ century B.C., and the latest can be dated to the third century A.D. His cult gained a huge popularity 
throughout the Roman Empire where he represented one of the eastern mystery cults. The prevailing thinking is that Sabazius is a Thracian deity brought to Asia Minor by the Phrygians and his cult was common principally among the Roman soldiers. He was a Divinity of fertility of the earth and women, vegetation [7, 16], protective of agriculture, and a potent deity against the evil eye and dangerous animals; such as snakes and crocodiles. Most of the symbols and attributes attest the syncretistic tendencies of the Sabazius cult. As it is very well known, the pine-cone is associated with Dionysus. An ancient literary evidence attested a close link between Sabazius and Dionysos since the beginning of the $3^{\text {rd }}$ century B.C. which established the connection between Sabazius and the pine-cone [3]. Sabazius was like Dionysos who appears as an orgiastic deity. Moreover the basket was an important feature of the cult of both Sabazius and Dionysos; it initiates in the Sabazius cult, as in the Dionysos worship. They carried cult objects like the kiste (a sacred basket in which a serpent was kept) and the liknon or winnowing-basket [3]. This relation answers the question, why is the pine-cone one of the most attributes close to Sabazius hands? And explain the strong relation between Sabazius and Dionysos. The snake, as well as the pine-cone, was always prominent in Sabazius cult. The strong connection between Sabazius and the snake can explain to us why this animal is going to accompany the god in different arts? The existence of the snake goes in two directions. On one hand, according to Clement of Alexandria, a snake was drawn through the bosom of the initiates, and the serpent is an incarnation or manifestation of the god [3]. On other hand, Sabazius, like Asclepius, has a particular connection with snakes. The common feature between both gods is the function of the healing divinity. This fact is attested by dedications and votive objects presented to Sabazius and are found in the main cult-centers of Asclepius. There are two dedications to Sabazius from Asclepius' great sanctuary at Epidaurus, and an inscribed hand is found in the Asclepieion on the south slope of the Athenian Acropolis [9]. We do not know exactly why is the hand used as a strong symbol that expresses the god Sabazius and the most important ex-voto to represent the god especially in military and household fields? Maybe because it was an epiphanic reminder that the hand is the first member of the human body that humans discover at birth [17]; and as noted, Sabazius was a protector god of childbirth. Perhaps also the hand of a god incarnates his saving power [3], and has the powers aimed at controlling all aspects of life and carries the good for the humanity including fertility. Thus we find hands decorated with various attributes and symbols related to all affaires of life and also a woman nursing her child, and with all these symbols, the whole world is in the hand of Sabazius. A similar understanding and meaning of symbolism of the hand is found in ancient Egyptian beliefs. We find passages and forms in the ancient Egyptian iconography; religious texts and hieroglyphs referring especially to the regeneration and life-giving power of gods and goddesses and these powers are associated with the hands. The Egyptian amuletic hand was believed to give the power of dexterity and manual agility [17], and the amuletic value of the open hand is power of action [18], for this reason the divine hand is connected with the creation idea and represents a symbol of creative energy as well as protective power [19]. According to the Egyptian myth and Heliopolitan system, that Atum, the primeval god of Heliopolis, is the creator of people and all other beings. Atum emerged from the initial chaos, 
which was conceived of as a dark, created the first couplet of gods Shu and Tefnut by an act of masturbation with using his hand [20]. Atum brought his erected phallus and then engulfed his own ejected sperm, and his mouth played the role of vagina; for that, the Atum hand was considered to be sacred [21]; so that we find the Atum's hands are mentioned often in magic literary [20]. In the same context, probably we find a phallus on the hands of Sabazius. This action associates Atum's hand with a goddess responsible for fertility and sexual pleasure like Hathor. In the ivory or wooden Hand-shaped clappers which were used in music and dance in ancient Egypt, the hand is decorated with a mask or face of Hathor (fig. 4), and as we know Hathor represented the female creative principle and was given the epithet 'Hand of Atum' [19]. We can notice the place of the mask of Hathor on these clappers which reminds us of the bust or figure of Sabazius on his hands. The noise of cymbals and castanets were thought to drive out the evil forces and dangerous spirits in ancient Egyptian rituals [19]; and that perhaps explains the main reason of the existence of a cymbal or two cymbals on Sabazius hands to do the same function.

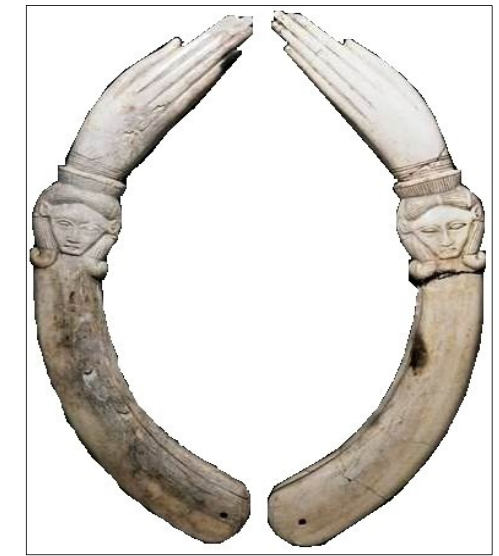

Figure (4) Pair of clappers from Thebes, Egypt, new kingdom (Pinch, G., 1994).

\subsection{Sabazius in Egypt}

The most important question in this study is still the details of Sabazius cult in Egypt, where the Syncretism in the development of Sabazius cult played a certain role in associating the god with other divinities especially the Egyptians, as well as the use of the hairpin. The cult of Sabazius exists alongside other gods and cults, and is taken as facts of everyday life in all Greco-Roman world. Also this cult encircled the Mediterranean area and different sites $^{(\mathrm{m})}[3,9]$, and this hairpin presents a new evidence for Sabazius cult in Egypt. As mentioned previously, Sabazius was one of many oriental gods worshipped by Roman army soldiers, who played an important role in the propagation of the new religions [9], and in the spread of the cult of Isis, Serapis and other Egyptian gods. The worship of Sabazius depended on various syncretistic forms as Zeus Sabazius or Dionysos Sabazius [3], and is identified with Isiaca, so that we find Sabazius adopting the attributes of Isis especially the sistrum [10]. Sabazius is called $\varepsilon \pi \eta$ ஸिо (listening to prayer) which is likewise a widespread epithet applied to Sarapis [3]. In another inscription,

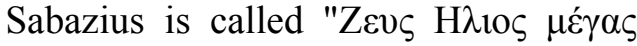

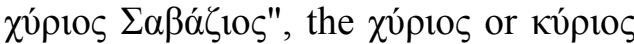
(having power or authority over, lord, master and guardian) is attested for Sabazius in other Thracian inscriptions, and is of course known for other gods such as Sarapis [9]. The only known literary evidence for us of Sabazius cult 
in Egypt comes from a papyrus found in Oxyrhynchus, dated by the third century A.D. It contains an invitation to a marriageparty mentioning a person called Dioscorous invites unknown person to dine at the wedding party of his son in the temple of Sabazius, not previously known in Oxyrhynchus [22, 23]. Besides the literary source, there is also a very rare iconographical evidence from Egypt; Just a round bread stamp from site of Tell Atrib in Delta, fig. $(5-a)^{(n)}$ [24]. It bears a figure of Dionysos-Sabazius depicted by front, with naked torso, upraised arms, snaked lower part, inside floral wreaths. This motif suggests the production of local flour which related to the Dionysiac rites. Some scholars think that, a votive bronze hand (possibly 1st century A.D.) is an Alex-

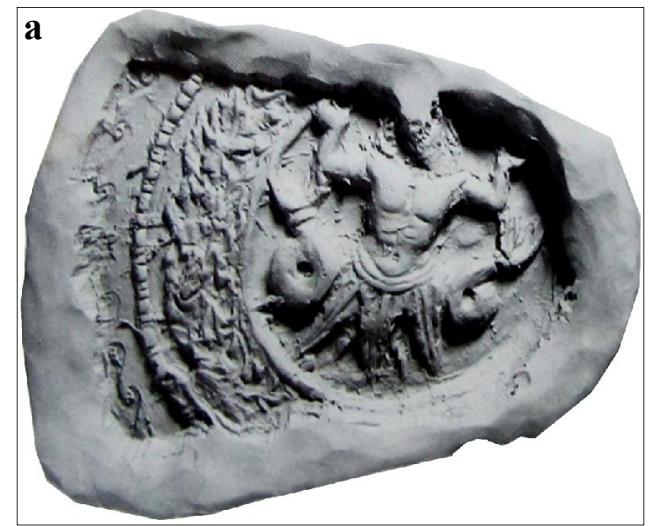

andrian work and the bust on the palm is for the god Zeus-Serapis [25]. This hand shows the first three fingers are extended while the little finger and ring finger are folded into the palm in the form of benedictio Latina, fig. (5b) ${ }^{(0)}[5,15,25]$. The front of the wrist is decorated with a reclining woman inside a cave, as well as two insects, and a bust of bearded male, his head carries a Phrygian cap that characterizes the god Sabazius. There is a pine-cone on the bent down two fingers, and on the tip of the Thumb a half-moon shaped object perhaps a worm. There are also a turtle on the back of the hand, as well as a large lizard in the middle, a Kantharos, a snake is moving its head to the right towards the little two fingers, a frog or toad, a whip, and a balance.

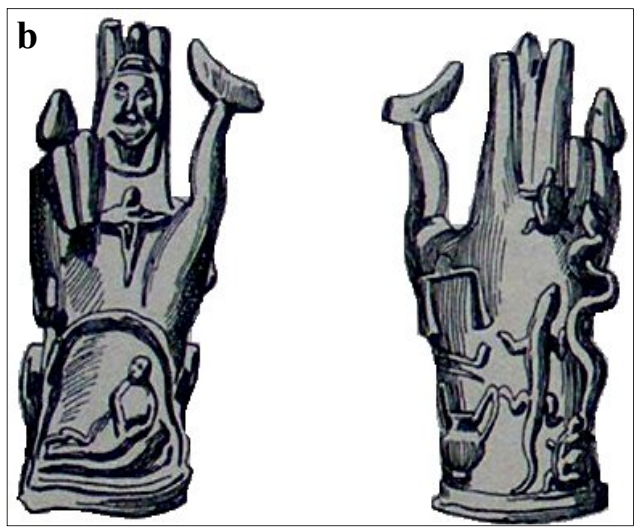

Figure (5-a, b) ‥ A bread stamp from Tell Atrib carries a figure of Dionysos-Sabazius (Myśliwiec, K.,

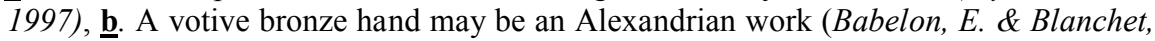
J., $189 \overline{5})$

\section{Discussion \& Significance}

The hand and its gesture have here a religious significance linked to magical and fertility rituals [17], and present an element in the Greco-Roman depicting contacts between the god and the worshippers. The same gesture of Sabazius hand with the fingers upraised in the gesture of the benedictio latina is perpetuated by Christianity $[2,14]$ and is still used in the Latin Christian rite as a sign of blessing ${ }^{(\mathrm{p})}$ [3]. The gesture of laying a hand on somebody is sometimes linked with healing, childbirth and protection. We find in ancient Egyptian texts spells to safeguard children. In a spell, Hathor is described as "laying her hand on a woman suffering in childbirth" [19]. Sabazius played an important role as a protector of childbirth. We have hands carrying a decoration on the front for a semi-circular caverna in which a reclining mother with her child nursing him $[5,11]$ fig $_{\text {s. }}$ (3-e, f), (4) \& (5-a, b). According to Tran Tam Tinh, also depending on many hands and many objects related, Sabazius was particularly venerated in the area of Pompeii and Herculaneum as a 
protector of women in labor [15]. The same motif is found in Egypt. Egyptian tomb scenes show cattle and a figure making a special protective hand gesture which shows a similar gesture to Sabazius gesture with little difference. The hand is stretched to the front with the little ring and middle fingers folded into the palm but the other two fingers are extended. The same gesture is made by a man in scenes of animals giving birth, fig. (6)[19]. Amulets based on this gesture form were worn by the humans. The gesture seems intended to protect animals as well as humans in time of crisis. Many Roman hairstyles involved the use of tight curls, made with hot tongs, and some of these pins would have been toilet instruments. Many Roman hairpins are used for arranging the hair or for fastening the hair in place rather than as ornaments as we see in our hairpin. A similar hairpin of bone from Pompeii is shaped like a hand making the gesture of the benedictio Latina $^{(\mathrm{q})}$ [26], with three fingers that hold a round object, $1^{\text {st }}$ century A.D. Other two Hairpins in ivory are probably from Tharros $^{(\mathrm{r})}$ [5]. The hairpins end in a hand making the gesture of the benedictio Latina. Let us ask about the main functions of both, the hands and hairpins. Some scholars think that, the priests may have distinguished themselves from the average worshippers by wearing such hairpins [9], but I think the function of both the hands and hairpins with the attributes of the god are small religious and magical objects, so the hairpin here covers a wide range of interpretations or functions including the fertility, initiation, protection and various structuralism views. The hand with this gesture is used as an amulet against the evil eye long before the Christian period [2]. The previous suggestion depended on the form of the hairpin which recalls the staff of the god Sabazius. Such reliefs represent the god holding a staff surmounted by a hand and frequently the bronze hand of Sabazius can be fixed on top of the god staff [3], and in the light of that, this kind of artifacts may represent a ritual object used to bless the worshippers and followers in Sabazius cult. The hands were carried during processions in honor of Isis, and the hand was put at the end of a stick in ceremony sacrifices of Isis; and the type of these hands were carried out in relation with Isiaca [8]. Also ivory rods ending in hands from Egypt represented the divine Hathor hand and were part of a magician's equipment [19]. In this direction, we find Sabazius cult was not limited to just as a Divinity of fertility and vegetation $[7,16]$, but was also a protector of women in childbirth, a protector against the evil spirits, especially the evil eye [15]. Various ways were used to help and protect women, one of these is the hairpins which are decorated with attributes of gods and goddesses like Sabazius which was linked to both human and crop fertility. Many worshipers regarded Sabazius as the god of foreigners, both the higher ranks and the lower classes [3], in addition to soldiers and slaves. On the basis of the existence of the snake that is connected with the gods of healing, Sabazius and Asclepius, it might be suggested that the choice of the hairpin is to present also the idea of the god's healing touch [9]. All that suggest that the hairpin is used by women to do all the previous functions, especially the hands connected with cultic or votive meaning and the Sabazius-worshippers looked at their god as a supreme deity [9]. The excavation of Sais, where the hairpin was discovered, supports this idea. The excavation report refers to that ${ }^{(\mathrm{s})}$ the hairpin was found, presumably, in a civic building very close to the bathhouse of the city. This building has walls of brick, an oven of mud-brick, a very huge vessel of pottery, lamps and a limestone altar inside a room. 


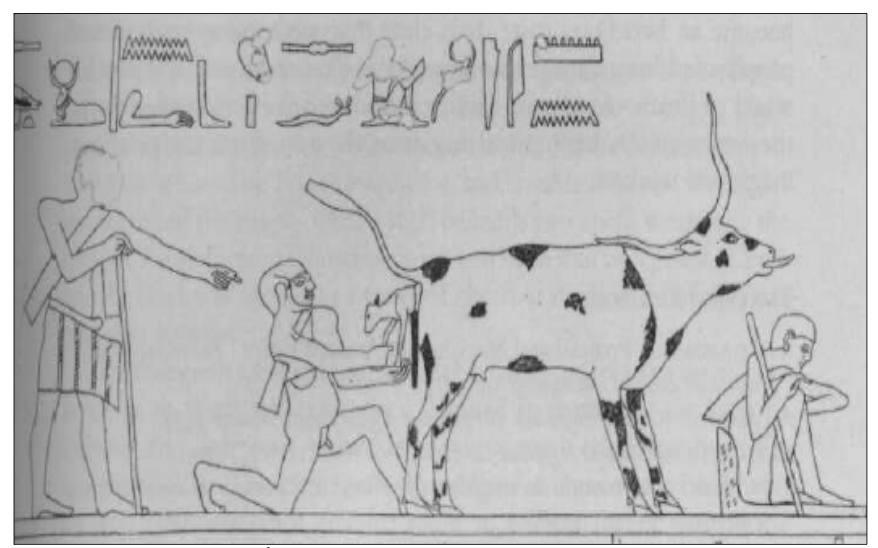

Figure $(5-a, b)$ A relief from Meir, $20^{\text {th }}$ century BC., shows a man- makes a Magical gesture to protect a newborn calf., (Pinch, G., 1994)

\section{Conclusion}

The cult of Sabazius spread in the entire Roman Empire; so that probably a little chapel in honor of Sabazius was built in Sais. And the hairpin from Sais bears witness of Sabazius cult among the people especially women there, and this hairpin appears as an amuletic or a magic object with protective functions, especially for the mother and child during childbirth, the household against demonic attacks and evil spirits. In the light of the poor evidences form Egypt for Sabazius worship, we can recognize that his worship in Egypt never received official divine status. It seems that he was not a known god in Egypt during the Ptolemaic period and his cult was not very popular during the Roman time. Sabazius was a part of the household worship, and the motif of hairpin with Sabazius hands gives us an insight into the themes and needs of the families of those days like the various female and earth fertilities, motherhood and childhood. This hairpin probably goes back to the period from the $1^{\text {st }}$. century to the $3^{\text {rd }} \mathrm{A}$ $D$.; since most objects related to Sabazius cult are dating by this period.

\section{Endnotes}

(a) Excavation Report of season 19811982, from 2-2-1982 to 5-5-1982.

(b) Present day the Village of Sa el-

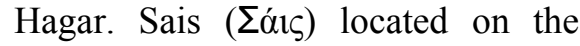
right bank of the Rosetta branch of the Nile. Sais was the capital of the $5^{\text {th }}$ lower Egyptian nome. The main cult at Sais was the goddess Neith which was identified with the Greek goddess Athena, as well as other deities like Isis, Osiris, Horus, Hathor and Atum. Málek, J., (1984). Lexikon der Ägyptologie, V, s.v. Sais, Wiesbaden; Myśliwiec, K., (2001). The Oxford Encyclopedia of Ancient Egypt 3, s.v. Sais, Cairo.

(c) Tanta Museum, Inv. TA. 1287. Excavation no. 276.

(d) Jupiter Dolichenus was god of a Roman mystery cult, fertility, thunder, and recognized as a god of the heavens but was also believed to control military success and safety. He appears as a fighting emperor standing on the back of a bull, decorated with the ægis, and sometimes a sword. He was usually represented standing on a bull and carrying his special weapons, the double ax and the thunderbolt. $\mathrm{He}$ was closely associated with the cult of Isis, Serapis and Mithras. The wors-hip of Jupiter Dolichenus moved to Rome and other centres, where it became extremely popular during the $2^{\text {nd }}$ and $3^{\text {rd }}$ centuries AD. Speidel, M. P., (1980). Jupiter Dolichenus: der Himmelsgott auf dem Stier, Stuttgart; Wirth, H., (2010). Die Linke Hand, Wahrnehmung und Bewertung in der griechischen und römischen Antike, Stuttgart. pp. 122123, Abb. 6; Hörig, M. \& Schwertheim, E., (1987). Corpus Cultus Iovis Dolicheni (CCID), Études Prèliminaires aux Religions Orientales dans L' Empire Romain 106, (Leiden) 
43-7, nos. 40-41, Taf. XIII, 170, Nr. 262, Taf. XLIX.

(e) Museum of Art and Archaeology, Columbia, no. 71.139.

(f) Naples, museo nazionale, seems to be lost.

(g) Found in Vada Sabatia, London, British Museum, Inv. No. 1898.1119.1.

(h) From Cappadocia, Caesarea. H.8.7 $\mathrm{cm}$.

(i) Provenance unknown, Brussels, musées royaux d'art et d'histoire, inv. no. 440A.

(j) Pompeii Antiquarium, inv. No. 10486, found in the house of the Birii (II,i.12), Max. H.18 cm. H. base $2.7 \mathrm{~cm}$., diam. base $3.5 \mathrm{~cm}$.

(k) (found at Resina, situated upon the ancient city of Herculaneum in 1746, Naples, Museo Nazionale, inv. 5506, H. $18 \mathrm{~cm}$; W. of base $8 \mathrm{~cm}$.

(1) We find also in Greek $\Sigma \alpha \beta a ́ \zeta o \zeta$,

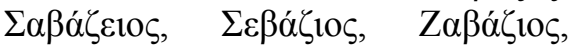

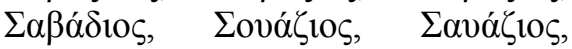

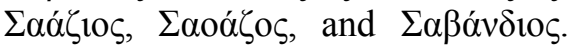
Other forms are found In Latin like Sabasius, Sabadius, Zabazius, Savadius, Sabazus, and Sebadius.

(m) It was attested by the literary and archaeological evidences in Athens, Macedonia, Asia Minor, Thrace, as far east as Cappadocia. There are

\section{References}

[1] Bartus, D., (2012). Roman hairpins representing human hands: Typology and symbolism, in: Szilvia, B., \& Péter, V., (eds.) Firkák II. Fiatal Római Koros Kutatós II. Konferenc IAKötete, Mursella Régészeti Egyesületé $\mathrm{s}$ a szerzők, Györ, pp. 205-233.

[2] Elworthy, F., (1895). The Evil Eye: An account of this ancient and widespread superstition, Murray, J., London.

[3] Johnson, S., (1984). The Present state of Sabazios research, Aufstieg und Niedergang der Römischen Welt, Vol. II, (17.3), pp. 1583-1613.

[4] Blinkenberg, Chr., (1904). Archäologische Studien: Darstellungen des dedications to Sabazius in the Islands of the Aegean, the Cyclades, Piraeus and Epidaurus. Also there is evidence from other places as Rome, Ostia, Tibur, Campania, Pompeii and other parts of Italy as far north as Cilicia and Sardinia. Sabazius cult was found in the eastern Mediterranean, especially in Cyprus and Rhodes. New finds related to his cult are from Dacia, Spain, and Gaul; from Germany, Austria, Hungary, Britain and North Africa.

(n) Storing room of Tell Atrib, TA 94/27, diam. $0.045 \mathrm{~cm}$. Parts are lost in different places, $2^{\text {nd }}$. cent. BC.

(o) Bibliothèque Nationale, Paris, inv. 1046.

(p) There is an agreement now that, the gesture of benediction is not adopted by Christians from the Sabazios cult, nor did this cult borrow it from Judaism; it is just part of a tradition was widespread in ancient times.

(q) Pompei, SAR, inv. 55484 (ex.2998). Length $10.2 \mathrm{~cm}$.

(r) Cagliari, archaeological museum, without Inv. no. (L. $11.3 \mathrm{~cm} \& 12.3$ $\mathrm{cm}$ ).

(s) Excavation Report of season 19811982, from 2-2-1982 to 5-5-1982.

Sabazios und Denkmäler seines Kultes, Gyldendal: Nordisk forlag, Kopenhagen

[5] Vermaseren, M., (1983). Corpus Cultus Iovis Sabazii, (CCIS): The Hands, Brill, E. J., Leiden.

[6] Anamali, S., (1988). Albanien: Schätzeausdem Land der Skipetaren, Philipp von Zabern, Mainz am Rhein.

[7] Conticello, B., Varone, A., \& dell' Orto, L., (1990). Rediscovering Pompeii, L' Erma di Bretschneider, Roma.

[8] Willems, H. \& Clarysse, W., (2000). Les Empereurs du Nil, Peeters Publishers, France. 
[9] Lane, E., (1989). Corpus Cultus Iovis Sabazii, (CCIS): Conclusions, Vol. III, Brill, E. J., Leiden.

[10] Tran Tam Tinh, V., (1971). Corpus Cultus Iovis Sabazii, (CCIS): Le culte des divinités orientales à Herculanum, Vol. 17, Brill, E. J., Leiden.

[11] Berry, J., (2007). The Complete Pompeii, Thames \& Hudson, London

[12] Bodson, L., \& Orr, D., (2002), Amphibians and Rebtiles: Evidence from wall painting, mosaics, sculpture, skeletal remains, and ancient authors, in: Jashemski, W. \& Meyer, F. (eds.) The Natural History of Pompeii, Cambridge, pp. 327-337.

[13] Turcan, R., (1993). Sabazios à Pompéi, in: De Conte, M., Gallo, E., \& Mazza, C., (eds.) Ercolano 17381988, 250 anni di ricerca archeologica, "L'Erma" di Bretschneider, Roma, pp. 499-512.

[14] Ward, A., \& John, P., (1977). Pompeii AD 79, Exhibition 20 Nov. 1976 - 27 Feb. 1977, Royal Academy of Arts, Piccadilly, London, $1^{\text {st }}$. ed., Imperial Tobacco Ltd. London.

[15] Tran Tam Tinh, V., (1972). Corpus Cultus Iovis Sabazii, (CCIS): Le culte des divinités orientales en Campanie, Brill, E. J., Leiden.

[16] Jashemski, W., (1979). The gardens of Pompeii, Herculaneum and the
Villas destroyed by Vesuvius, Caratzas Brothers, New York.

[17] Achrati, A., (2003). Hand and Foot Symbolisms: From rock art to the Qurān, Arabica, T. 50 (4), pp. 464500.

[18] Petrie, F., (1914). Amulets, Constable \& Company LTD, London

[19] Pinch, G., (1994). Magic in ancient Egypt, British Museum Press-London.

[20] Kákosy, L., (1975). Atum, Lexikon der Ägyptologie, Vol. I, Otto Harrassowitz, Wiesbaden

[21] Myśliwiec, K., (2004). Eros on the Nile, Cornell Univ. Press. Ithaca

[22] Rea, J., (1968). The Oxyrhynchus Papyri, Vol. XXXIII, No. 2678: Invitation to a Marriage-feast, The Egyptian Exploration Society, London.

[23] Burkert, W., (1987). Ancient mystery cults, Harvard Univ. Press, Camb-ridge.

[24] Myśliwiec, K., (1997). Les ateliers d'Athribis ptolémaïque", Archeologia, Vol. XLVII, pp. 7-20.

[25] Babelon, E. \& Blanchet, J., (1895). Catalogue des bronzes antiques de la Bibliothèque Nationale, Ernest Leroux, Paris

[26] Ciarallo, A.\& De Carolis, E., (1999). Homo faber: Natura, scienza e tecnica nell' antica Pompei, Electa, Milano. 